\title{
The intimate spaces of debt: love, freedom and entanglement in indebted lives
}

\author{
Leila Dawney, Samuel Kirwan and Rosie Walker
}

\begin{abstract}
In the context of a perfect storm of measures - welfare reform, precarious work, stagnating wages increasing numbers of households find themselves in complex webs of debt. This paper addresses the lived experience of debt in the UK, tracing some affective contours of indebtedness that are often overlooked in debt research. Focusing on domestic settings and emotional routines, the paper explores how the everyday experience of indebted life seeps into relationships, frames life projects, and mediates hopes for one's children.
\end{abstract}

The paper argues that the affective architecture of debt operates just as much through moments of intensity - the letter of default, the pressure cooker of an advice session - as through a background hum in which individuals are engaged in ongoing practices of self-assessment, despair, desire and satisfaction. Drawing on in-depth interviews with indebted subjects, this paper investigates contemporary financial subjectivities through such forms of affective modulation that "run in the background". In addition to those moments of intensity, it argues that indebted lives are composed through low-level affective states that include hypervigilance, dissociation and anxiety. It examines the deep entanglements of people, technologies and objects that produce these affective states, highlighting relations of obligation and codependency, and the forms of vigilance and anxiety these relations create. In doing so, the paper troubles understandings of debt as a binary relationship between creditor and debtor and argues for a perspective that considers the complex affective entanglements of indebted lives and the imbrication of indebtedness, financial subjectivity, love and care in the making of life projects.

\section{KEYWORDS}

Debt, affect, financial subjectivity, emotion, anxiety, hypervigilance

\section{Introduction}

Riding the escalator at Gatwick Airport railway station, I pass a row of electronic advertisements for the ClearScore app, which offers me free credit checking on my mobile device. I search for it on my phone, and find out that Clearscore is a fintech startup, offering a similar service to the US-based Credit Karma. It offers free credit scores in exchange for advertising and selling a range of financial services, such as credit cards and car and personal loans. I install the app and find the background image is the same as the poster, a lone walker on the top of the mountain: an image of nature, freedom and escape. When I check my rating, the Clearscore algorithm interfaces with users as a "counting-up" of numbers. As the numbers mount and settle on a final figure, I feel a buzz of satisfaction.

Research Diary, Author $1(2 / 5 / 17)$ 
This paper addresses the lived experience of debt in the UK. This is a subject of increasing importance in the context of a perfect storm of measures - welfare reform, precarious work, stagnating wages - the effect of which is that increasing numbers of households find themselves in complex webs of debt: to banks and credit card companies, doorstep lenders, payday and other high-cost lenders, local and national government agencies, utility companies, hire purchase providers and others (Kirwan, 2018). While levels of consumer credit grew to such an extent between 2011 and 2017 that the Bank of England issued a warning on their 'rapid rise' (Bank of England 2017), the primary concern for debt charities is what such credit was being spent on, with increasing numbers of households turning to high-cost credit to meet essential household expenditure (StepChange 2017).

In such circumstances there is growing recognition that the experience of debt - of the emotional consequences of relying on credit and being beholden to one's creditors - is the defining experience of life under conditions of 'austerity' (Lazzarato, 2011). There is a growing body of work, including by ourselves (Kirwan 2018, Kirwan, 2016) examining how austerity measures are pushing increasing numbers of households into debt. Yet we seek in this paper to take this observation on the proximity of debt and austerity in a different direction. By examining the everyday affective registers that define life in debt, we explore austerity not as external constraints but as a domain of experience; as a particular constellation of attachments, emotions, intensities and rhythms. In this respect we follow the work of Martijn Konings (2015), who has sought to trace a genealogy of austerity as a modality of belief. By tracing particular Christian moral orderings of the world through the moneyfaith nexus, Konings identifies the popular imaginaries - in particular the promise of 'purification' brought by restrictions upon welfare spending - through which policies of austerity found their force. In thinking through the experiential domain of austerity, we turn to recent work in affect theory which addresses the affective and experiential registers of contemporary forms of life. In particular, we turn to the work of Lauren Berlant and Kathleen Stewart, whose 'scenological' analyses attempt to articulate the processes through which economic processes become manifest in modes of relating to the world in the affective life of austere capitalism. Through this conceptual lens, we consider how these discourses and policies resonate with particular domains of experience, namely those particular to life-in-debt, and how these have, in turn, been amplified by austerity policies.

In investigating this experience, we take our cue from the questions raised by the above advert for Clearscore, tracing as it does some affective contours of indebtedness that, for reasons we set out, are often overlooked in debt and austerity research. What is it about the everyday experience of debt - by which we mean, for example, the way that it seeps into relationships, or frames hopes for one's children - that allows the management of one's credit rating to be packaged as a space of calmness and safety? If debt is characterised by anxiety, fear and enforced self-discipline (Lazzarato 2012), how is it that a service exacerbating one's attachment to debt and its effects can be presented as a moment of release?

Drawing on interviews with indebted subjects, this paper investigates contemporary financial subjectivities through forms of affective modulation that "run in the background". We suggest that, in addition to certain moments of intensity (such as the moment of default or the bailiff visit), indebted lives are composed through low-level affective states that include heightened attention, dissociation and anxiety. We also consider the means through which indebted subjects work to regulate and mitigate these experiential zones, often through practices that tie them more securely into indebted relations. The paper examines the deep entanglements of people, technologies and objects that produce these affective states, highlighting relations of obligation and co-dependency and the vigilance and anxiety these connections create. In doing so, this paper troubles understandings of debt as a binary relationship between creditor and debtor and argues instead for 
a consideration of how indebtedness, financial subjectivity, love and care are imbricated in the making of life projects.

The paper proceeds as follows. We first set out the research methods behind the project, emphasising how the recruitment of participants and interview schedule were designed to draw out these affective modulations and entanglements. Next, returning to the above-described adverts for Clearscore, we present the particular contribution we seek to make in the article to the growing literature on debt as a relational and affective space. We do this by drawing upon affect theory to describe indebted subjectivity as low-level intensity or 'background hum'. The paper then examines three forms through which these affective modulations play out in our interviews. Firstly, we turn to the concept of hypervigilance, in order to examine the ways in which people develop an alertness to their financial lives, and how this alertness relates to life projects. Secondly, we engage with Berlant's concept of slow death, arguing that indebted life is often coloured by the knowledge that there is no escape, that the attachments produced merely consolidate our relations with financialised life (Berlant 2011). Finally, we discuss forms of escape: the means through which this discomfort is suspended. This concerns in particular those moments where hypervigilance - as a structuring condition of indebted life - necessitates practices that lead to a temporary way out, even though these practices might draw us ever closer to the modes of being we are trying to escape from.

\section{Research Methods}

We have taken an approach to studying the everyday life of austerity that moves away from the dominant figures and discourses of "Austerity Britain" (O'Hara 2015), centred on the extreme effects of welfare reform (Morris 2016), legal aid cuts (Hynes 2013) and precarity of employment (Standing 2016). There are, we argue, important stories to be told about the affective condition of those on low-to-middle incomes for whom the effects of austerity measures are less apparent, but whose narratives also indicate the living of austerity as an experiential and affective domain. In this respect we follow Lauren Berlant's observations, detailed below, on austerity as both discipline and attrition.

As such this project involves interviews with participants who, while struggling with their debts, do not consider their debt to be a 'problem' they cannot solve. The research thus recruited individuals and households that typically fall outside of the usual remit of debt research, which has tended to focus upon individuals who have defaulted upon one or many debts, become insolvent, engaged a debt management service or sought debt advice. ${ }^{1}$

Our project, then, addresses debt and indebted life with those for whom it is "just part of life", beginning with the premise, articulated by the debt charity StepChange, that debt is the "new normal" (Santos 2015). While these are individuals with both complex and high debt burdens that often take up significant proportions of their household income, their debt has never reached 'problem' status, or its subjects have actively chosen not to address it through the framework of the debt advice process (see Kirwan, 2018). They may have considered insolvency or a consolidation, but have not pursued these options.

We conducted 8 interviews between 1 and 2 hours with participants who had never sought formal debt advice from a government or charity agency. While the sample is small, the interviews involved a high level of detail about participants' financial lives. Participants were recruited using a snowball method beginning from personal contacts and social media. Whilst potentially limiting the sample,

\footnotetext{
${ }^{1}$ There are important practical reasons for orienting research around the advice sector. Atfield et al's ten-year longitudinal project, for example, provides a defining overview of debt burdens in the UK (Atfield, Lindley et al. 2016). Yet being part of the advice system already assumes a particular relationship to personal debt, and the goal of the debt advice process to "reshape clients' emotional attachments" (Kirwan, 2016).
} 
the advantage of using personal contacts was that the sample need not be restricted to the client base of a particular institution. This resulted in a group of interviewees across the UK with varied income levels and debt burdens. The interviewees were 4 men and 4 women of differing ethnic and class backgrounds, and with very different levels of income, capital and social standing. This coincided with our interest in exploring austerity as a generalised, experiential condition, which participated differently in variously situated lives. Alongside this, we undertook field diaries of our own affective encounters with our finances, which we discussed with each other at workshops during the course of the project. During these workshops, we drew on our field diaries alongside collaborative discussion of academic literature as a means of working towards the conceptual and theoretical shaping of the project. In addition to focusing upon levels of debt and hopes for repayment, the interviews addressed the relational and affective spaces in which these hopes, timescales and practices were embedded, through a focus on relationships, attachments and practices of love, care and abandonment. The interviews began with a general discussion of their life situations, and then moved to the specifics of dealing with finances. As the interviews progressed, the steered between these spaces, paying attention to both the affective worlds described and the material practices and articulations of life-making through which these affective dimensions played out. The formal advice process encourages people in debt to see their debt as separate from life. In contrast, this study allows participants to express their financial lives as imbricated with situations, relationships, desires, loves and debts.

\section{Affect as low-level intensity}

To accompany its billboard campaign, Clearscore launched a series of television adverts involving couples and families interacting with the app on various screen-based devices. We see Charlie and Lauretta, and their dog Moose, in a number of "everyday" domestic scenarios: with the laptop at the kitchen table; on a sofa in the lounge with a smartphone. In these advertisements, Lauretta asks Charlie to check his credit score, which he does easily. In Wedding and Dogs Can't Drive, ${ }^{2}$ Charlie uses the same app to look at loans. In another, we see Mick, his partner Patricia and cat Flearoy, relaxing together in bed. Mick checks his credit rating on a tablet and announces that the app offers him "total control of my money".

In these adverts, Clearscore seeks to re-frame the multiple screens that inhabit and re-compose the contemporary home as sites of financial promise and self-regulation. Its advertisements normalise a continued engagement with one's financial subjectivity; drawing on the affective lures of selfevaluation that constitute contemporary digital interfacing (likes, feedback and ratings) to provide dopamine hits (Dean 2010) in exchange for involving subjects in domestic routines of financial service selling and providing credit scores.

Importantly, front and centre of these imagined routines is the (heterosexual) couple relationship and the domestic space formed around it. Lauretta, in her role as demander of credit score checking, maintains a level of anxiety and alertness around the couple's credit rating. Charlie's checking of the app offers reassurance, promise and a means of strengthening the collective project of domestic life in partnership. The shared relaxation of Mick, Patricia and Flearoy similarly flows from the mastery Mick experiences over his financial self. In these stagings of anxiety, control and release, in which the domestic space and financial subjectivity are indistinguishable, a particular promise takes shape. The app provides a dopamine hit, as one (re-)checks a marginally improved credit score or gains access to further credit - a hit that can be accessed on a grey commute, or in the sunken minutes

\footnotetext{
${ }^{2}$ The titles given to the adverts on Clearscore's Youtube channel. Both can be found at https://www.youtube.com/watch?v=Yl_WVr66nYs and https://www.youtube.com/watch?v=x91ypZvUYil
} 


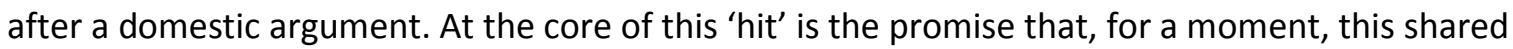
life, otherwise defined by the pressures and demands of indebtedness, can be made liveable.

Considering the growing influence of the Credit Referencing sector in the UK, it is important to note that the use of statistical information to inform application screening in consumer finance is not new. Martha Poon (2007) tracks the development of the credit 'scorecard' in the United States as a 'market device' through the 1950s and '60s. The marketing of credit reference products to borrowers however began in earnest in the 1990s (Langley 2014). This shift has brought greater interest from the social sciences in the credit referencing system, implying as it does a fundamental shift in the power of the financial system to shape everyday practices. This has been primarily interpreted through Deleuze's model of the 'societies of control' (Langley 2014). The extraordinary growth and complexity of credit referencing systems, and their fusing with social media information (Zhang et al 2016; Deville 2013), seem to promise a world where financial transactions and sociospatial possibilities exist in co-constitutive proximity (Seigworth 2015).

We are less interested in this paper in the specific, punctual moments when one's credit score might intervene into one's life, ${ }^{3}$ than in what this shifting relationship between one's 'real' and 'data' selves ${ }^{4}$ reveals about more enduring and mundane dimensions of the everyday. While the speculative accounts of Langley, Seigworth and others do seek to engage with a financialized everyday, following the focus on 'societies of control' combined with enduring disciplinary power, they tend to reduce it to varieties of restriction, whether internally or externally imposed. The more complex, and unexpected, emotional registers with which our material engages reveals a to-and-fro between intimate and financial registers characterized more by patterns of proximity, endurance and release.

In their foregrounding of domestic settings and emotional routines, the Clearscore adverts trace the ways in which debt operates just as much through moments of intensity - the letter of default, the pressure cooker of an advice session - as through a background hum in which individuals are engaged in ongoing practices of self-assessment, despair, desire and satisfaction. This paper is thus driven by a desire to attend to and unravel the mundane, the everyday, where politics are being played out through bodies without our noticing. If we do notice, we might misidentify it, because our affective responses can be channelled in ways that we are barely aware of. If our regimes of visibility are only trained upon the spectacular; if we can only register difference, then we need more than ever a politics of the ongoing, the attritional. In doing so, we can consider how certain public ideas, such as those associated with "austerity," attach themselves to bodies - how they resonate through lived experience and day-to-day striving. These ideas hook onto conditions and experiences of economic insecurity, resonating with people's lives as they are lived.

The paper thus speaks to a growing literature focused less upon the 'big picture' of debt relations levels of household debt, rates of repayment and interest, financial products - than the changing experiential modalities of being-in-debt. Debt relations are a complex ecology in which twistings of topological and topographic (Harker 2017) are reflected in practices of 'juggling' different debts with varying temporalities, moral codes and modes of enforcement (Wilkis 2015; Guérin 2014; Joseph 2014). Challenging the notion that family relations become 'disembedded' by money and finance (Cooper 2018), there is a growing body of literature, inspired particularly by the work of Viviana Zelizer, exploring how relationships are composed by concerns around money and debt. The rich ethnographies of Han, Bear and Davey across varied indebted settings have displayed the varied knowledges held by individuals and communities regarding the necessary mediation of intimacy and finance (Han, 2012, Bear, 2015, Davey, 2015).

\footnotetext{
${ }^{3}$ For example by stopping credit, preventing one from attaining a tenancy, or getting a job.

${ }^{4}$ The theme behind a second advert for Experian.
} 
Thus, considering debt and austerity, seemingly 'profligate' spending is often one of the primary means through which love and care are constituted (Miller 1998, Kirwan, 2018, Graeber 2011), while budgeting practices and spending decisions can also be tied to desires for 'quality time' together, hopes for one's children, and the care for other family members (Miller 1998, Hall 2016, Davey 2018). 'Care' for debts, and how they are monitored in the gendered division of labour within the household (Montgomerie and Tepe-Belfrage 2016), adds nuance to the idea of austerity as a necessary tightening of belts (Clarke and Newman 2012). Instead, we can observe the practices of love and devotion at play in the financial management of the household (Coleman 2016:90).

By focusing upon the emotional registers of debt and finance, picking up the everyday fluctuations of desire, hope and despair, we seek in this paper to give shape to the affective topology of indebted lives. While affect theory has customarily focused on movements of intensity, more recent discussions of the affective architecture of late capitalism have paid close attention to what we might understand as "low-level affects" 5 . These might barely register, yet provide a background structuring condition for the ways in which lives in the present are lived out. Among those thinkers currently associated with affect theory, it is perhaps Lauren Berlant and Kathleen Stewart who have paid closest attention to these flattened forms of affective life, and who provide the conceptual framing for our investigation.

Stewart's ethnographic writing focuses on the mundane space of the ordinary, paying attention to micro-atmospheres: states of vigilance, resentment and resignation that she encounters, where the self "exists, obliquely, in dreams of disappearing, of winning or being done with it all. Forms of attention and attachment keep it moving: the hypervigilance, the denial, the distraction, the sensory games of all sorts, the vaguely felt promise that something is happening, the constant half-searching for an escape route" (Stewart 2007:58). Through interweaving stories of stuckness, economic insecurity and infrastructural decline, the mundane incidents that give colour to the everyday compose the affective lives of austere capitalism: the small resentments, the moments of care, the arguments and the frustrations of lives focused on survival.

Berlant, too, pays attention to the modes of affect that often escape recognition, that operate at a lower intensity and whose work is attritional and insidious. Cruel Optimism charts the manifold ways in which we hold on to certain images of the good life, to forms of relationship, to life projects, to former ways of being in the world, in the hope that things will improve; in the hope that we'll 'get there' (Berlant 2011). Yet these images and dreams are no longer available to us, or perhaps they never were. Cruel optimism involves holding on to the promise of the post-war settlement, to the promise of secure employment, of home ownership or family life in the face of their inevitable failures. In the chapter "Slow Death", Berlant discusses obesity in dominant discourse and the role of food in exhausted lives, attempting to "recast this situation as a zone of temporality marked by ongoingness, getting by, and living on, where structural inequalities are dispersed and the pacing of experience is uneven and often mediated by way of phenomena that are not prone to capture by a consciousness organised by archives of memorable impact" (Berlant 2011). Slow death is characterised by an ongoing deterioration of a population, as a "defining condition of its experience and historical existence", a biopolitical process of the attritional production of modes of survival that are also modes of destruction, of "incoherence, distractedness and habituation" (Berlant 2011).

These thinkers offer a lens through which to pay attention to the affective architecture of late capitalist life, a shift in thinking about affect away from intensity or punctuating moments and towards those low-level affective modulations that position bodies towards each other and the

\footnotetext{
${ }^{5}$ Although it has a broad conceptual grounding, the concept of affect here is used in terms of Spinoza's understanding; as a process of increasing and decreasing intensity; as movement rather than stasis. The concept has been subject to a number of debates within human geography. For a comprehensive account of affect in the vein that we use it here, please see Anderson, 2014, particularly chapters 1 and 2.
} 
world. Our participants are frequently overwhelmed, exhausted, hopeful and resigned. ${ }^{6}$ Often these states are barely recognised. Instead, these forms of modulation form a low-level attritional intensity: a "background hum" that inflects life and is constitutive of indebted subjectivities and indebted relations that fold through the practices, habits and life projects that emerge in and through economic life.

Returning to the question of 'austerity', it is important to note that the lives of our participants would not fall into popular narratives of 'poverty'; they have not (yet) had to attend a food bank or been threatened with homelessness. Yet austerity as a field of emotions and attachments is nonetheless identifiable as a structuring condition for life that bleeds into and composes other relations (Konings 2105). The case studies we use emphasise the ambivalence of austerity, the way in which, as Berlant notes, it implies both askesis and destruction. Austerity is a demand that individuals become ever-more disciplined in their everyday, and an invitation to find recompense in "a sense of pride at surviving the scene of their own attrition" (Helms, Vishmidt et al. 2010). At the same time however, our participants' narratives also show attempts to mitigate against the discomfort of these scenes, adopting practices that temporarily take them out of themselves, or out of the constant managing of financial subjectivity. Tracing these different affective domains, we organise our research findings through the themes of 'hypervigilance', 'slow death' and 'escape'.

\section{Hypervigilance}

Hypervigilance is broadly understood as a psychological state, often brought on by trauma, of heightened arousal and anxiety. It is characterised by increased alertness to threat and by compulsive behaviours that can both reinforce or threaten the self. Children who experience trauma or are asked to take too much responsibility for themselves and others around them are likely to develop hypervigilant behaviours, such as constant scanning of the environment for danger. In our interviews, we became aware of practices through which financial lives became hypervigilant: everyday, domestic practices such as those in the Clearscore advertisements that this paper began with. In understanding hypervigilance as a low-level affect, we suggest that austerity stories of precarity and public decline fold through the life projects of our participants, such that their financial and domestic lives are inflected by their position in a game of speculation, entrepreneurialism and risk management, and in the "quotidian shuffling of debt among credit sources that has become typical among Americans" (Schüll 2012: 8). Barnwell's discussion of the concept in cultural theory discusses the emergence of a hypervigilant public, where "individuals try to be alert to how their attention is constantly being diverted toward spectres of prosperity, whether it is in the orchestrated detours of shopping malls or the wish-fulfilling images of advertising." She notes how the process of becoming 'wise' to the 'endless deferral' of these promises only makes us more attentive and vigilant. Indeed, "hypervigilance, as a form of responsive attention, is actually exacerbated by the notion that agencies beyond our control can arise from anywhere at any time" (Barnwell 2016:14-15). Her argument is that, as publics and as critics, we read the present with wariness. This hypervigilance, as a generalised condition that "runs in the background", is performative in its relation to other forms of affect - it provides the conditions of possibility for moments of intensity to arise.

Martin is a father of three in his late thirties. He lives in South Wales, and is currently working on a contract in the south east of England for part of the week and running a business from home for the other part. He is effectively attempting to do two full-time jobs in an effort to clear debts and fulfil the role of family provider, while his wife looks after their three pre-school children. During the interview, he assumes the role of financial responsibility within his family, occasionally casting his

\footnotetext{
${ }^{6}$ See also Povinelli 2011, 2016; also Baraitser 2017 for further work in endurance and exhaustion as modes of experiential life.
} 
wife as profligate in the process. His financial world involves a complex arrangement of spreadsheets, moving card balances, letting property, debt repayment and control. Everything is recorded on the spreadsheet, which is scrutinised regularly. For Martin, this form of financial micromanagement is central to his role as father and husband, as responsible caregiver. His love for his family is fulfilled through his financial responsibility. He demonstrates this through his modes of managing complex financial life.

Martin's hypervigilance is tied to his project of self and family creation, and as a project of atonement for past mistakes. During our interview, Martin produces his spreadsheet of income and outgoings, which he charts against his debts in a self-invented form of double-entry bookkeeping. The excel spreadsheet is proudly passed to me, and explained in detail: material evidence of his financial vigilance, recovery from past irresponsibilities and project of family prosperity. As we talk, Martin discusses how he brought debt into his relationship with his wife from a previous relationship. He compares this with the "path we've set ourselves now". For Martin, working two jobs, moving money around between credit cards and loans from friends and family is a means of marking out a life project as a solvent family man. His hyperawareness of his financial position is part of this performance of financial responsibility and speculative subjectivity:

So we've got about $£ 12,000$ on the credit cards, and we still owe on the loan about $£ 8,000$. Then I owe about $f 10,000$ through my business which is corporation tax and VAT. The car, I owe about $f 7,000$ on. There is other bits and pieces, but l'd have to refer to my spreadsheet. In total it's about $£ 50,000$.

While he discusses financial decisions in the first person plural, it is clear from the interview that he alone takes on the responsibility for financial matters. He sees debt as a short-term solution that he will work his way out of through close financial monitoring:

We'll take credit and borrow money to pay our outgoings on the basis that we can even that out in the future, rather than just not paying bills. Because then you start to get into... you know, you do you start to get records against you and then you do really struggle. We're quite aware of that, that's the tack we have taken, which has contributed to the debt.

Martin also orientates himself and his family towards a time in the future where the struggle will have paid off, and where there will be prosperity:

We have sweated blood and tears to get to where we are. But if we keep going on the current course of action, by the end of September this year we will be in a good position. I'll have a bit of debt within the company but all the other debts will be paid off then we'll have just the regular mortgage payment.

Although not so involved with the micro-management of his financial life, a similarly vigilant and speculative financial subjectivity can be seen in David's interview. A public sector worker based in East London, he owns a flat (with help from his family) and rents out a spare room to cover a sizeable proportion of his mortgage. His concern with the stagnation of public sector wages and increasing property values in London is reflected in his emerging commitment to speculative and property-related income generation:

I haven't had a pay rise in that time so it's like losing money on an annual salary. But I think that's quite common in the public sector since 2011. But part of the logic of owning property is that your salary increases... But obviously that's not quite the case if you haven't got the sort of job that has those pay reviews or if, like me, you haven't switched jobs enough. Maybe if I was a bit more ambitious in that sense... 
But improving your situation, now, just comes back to property. That's where the sense of it is, if there's any sense in my situation. If you bought something very expensive and it was becoming too expensive you would try to flog it so you know at some point down the line... that's the only way out. It keeps the limit on the anxiety, because barring something very serious happening to the housing market, which it might, there is a way out.

Throughout the interview, David discusses his worries and anxiety. In part, this seems to come from a belief that he does not have the complex financial skills needed to play the game and to maximise his position. David is juggling multiple debts, and he admits that this makes him worry, that he feels anxious about his position and the game he is playing:

So I've got the mortgage ( $f 115 k$ - $f 120 k$ left on it), The bank loan ( $f 12 k)$, The credit card loan $(£ 4,500)$, The family loan and the money from $L$ [girlfriend] ( $f 10 \mathrm{k}$ between dad and girlfriend). Then on top of that there is not strictly lending but it's kind of cash flow: my university fees (second masters degree) are late and so are my service charge payments for this flat. It's not an ideal way to play it, but the mortgage is obviously number one, you can't mess with the bank so whatever happens that one is paid. The University is flexible - they can wait a bit for fee payments, but not forever. There is a cost in terms of time and stress, spinning all the plates.

David's feeling of spinning all the plates, of doing his best to be a good financial subject, leads him to experience a constant low-level anxiety. He is in an advantageous position: he owns large amounts of capital, given to him by his family when he was in his twenties, his mortgage is relatively small and half of it is covered by his lodger, his long-term partner is a high earner, and David is taking a second Master's degree for personal fulfillment. Yet he feels out of control and his attempts to prioritise repayments are part of his regaining control. Rather than a fear that his debt will lead to poverty, his is a fear that his debt will not maximise his returns; that he will fail to spot a hidden rule in the game. In these two interviews, we see subjects participating in active and ongoing processes of financial management and speculation. Worry about the future is present in the need and desire for control, to lock down the alternatives in order to secure against the worst. Paying close attention to outgoings, moving debt around, checking credit ratings and attempting to manipulate them through financial transactions are all attempts find security in insecurity, in holding the future steady, in maintaining ledgers to guard against profligacy. Financial hypervigilance - or the playing of the game - forms an ongoing affective colouring of lives. The production of such concerned and vigilant financial subjectivities, however, also produces the conditions for failure.

\section{Slow death}

Berlant's concept of slow death describes a space of operation; a milieu of abandonment that produces affective states and practices that ultimately contribute to the destruction of life, yet may offer something more in the moment. It comprises those forms of medication that ameliorate the stress of exhausted life by offering comfort and escape: eating, sex, and 'spacing out,' or what Berlant describes as "regimes of exhausted practical sovereignty" (Berlant 2011:119). These are forms of survival; ways of shoring up the body against the slow violence of everyday life. Slow death includes states that operate under the surface, that don't necessarily emerge as anxiety or hope, or vigilance, but as a detachment: "impassivity and other politically depressed relations of alienation, coolness, detachment, or distraction, especially in subordinated populations, can be read as affective forms of engagement with the environment of slow death, much as the violence of battered women has to be re-understood as a kind of destruction toward survival" (Berlant 2011:66). Slow death involves "self-medicating activity that tilts toward self-destruction amidst overwhelming life" (Berlant 2015). 
Shelly's story addresses the role of close relationships in the wearing down of lives. She had been married to her first husband for a couple of years when she began to discover the debts he had. He had built up undisclosed credit card debts of between $£ 50 \mathrm{k}$ and $£ 100 \mathrm{k}$ before they were married and continued to accrue debt throughout their marriage, keeping vital details from her including private savings accounts that he had in his name. After Shelly worked to pay off most of his debts for him they eventually divorced, and she was forced to sell her business and flat at a loss. She remains in debt and has remarried. She has not pursued her ex-husband for money. She has had mental and physical health problems as a result of the experience and is on antidepressants. What became apparent during her relating of the story, is the "niggling sense of unease" she had in the early stages of their marriage, when her husband had not yet told her about his debts.

We actually did a marriage preparation course before we got married, and one of the things you do is talk about finances. For some reason we had separate sheets to make notes on, and I spotted out of the corner of my eye that he was writing something in the "do you have any debts" box. I just wrote all mine down... and then I looked back at his and he' $d$ crossed some stuff out. I thought 'oh that's a bit odd', but that was the only hint that anything was wrong. Then after we got married and I was working from home and so was he, on Saturdays when the post came I would hear him run down the stairs, pick up the post and run back up the stairs, and then I would hear the shredder going.

Shelly was caught in a financially abusive relationship based on low-level control. As a result, and because of her partner's denial of the situation, her ongoing sense of unease and financial instability continued, putting more and more pressure on her. Throughout the interviews, debts are associated with intimate relationships: they consolidate them, they rend them apart, they maintain them and lock people into ongoing financial obligations that cannot be separated from emotional and physical ties. People can lock others into their own destructive cycle; their own process of slow death through intimacy and control. Survival in indebted life involves complex entanglements of children, parents, friends, former and current partners, community leaders and neighbours. These entanglements often maintain difficult life situations: finances are the means through which family members and members of households control and are controlled, and shape intimate relations.

Amy's interview can help us to think about the experience of being "locked in" to debt, accumulating more debt and in the slow attritional role that this plays in her family life. Amy is in her early thirties and works in a bar. She lives with her two children and a new partner. She has various loans, including loans for a car and a sofa that she bought on finance, as well as credit card debts - some run up by her ex-husband and some by herself. Her ongoing struggle with her ex-husband's financial situation and lack of maintenance payments serves as a backdrop for her more recent debts. Amy, like most others we spoke to, imagines a debt-free time, yet as the interview progresses, it becomes clear that the horizon of this is retreating as offers of more credit lift her out of her 'stuckness'.

RW: do you think the debts you have affect your relationship with your partner now?

A: only that I moan at him that we've got too much of it. I think his loan is about the same as mine per month, and his car is a bit more than mine. So it works out at about $£ 700$ pounds a month that goes out on debt. I always say to him if we didn't have that we could have a lot more fun.

I'm really looking forward to two and a half years' time when we have paid everything off. It does really affect your life. Like, we're trying for a baby at the moment and I think all that money each month would make a massive difference. 
Amy's continual struggle to pay off debts, interspersed with taking out new ones, fold financial subjectivities through the lives of all her family members. Her attachments to her children, her partner and her parents play out through her desire to live a good life, to give her children what they want and need, and her inability to say no to the financial pressures of others. Most telling is a passage where Amy relates going on an expensive holiday to the USA with her parents that she did not feel that she could get out of, despite the fact that it would lead to a problematic debt repayment schedule on their return.

I had completely cleared my credit card the year before and I ended up having to run it up again keep saving to go for this holiday. Which we probably shouldn't have booked. But my mum and dad said my girls were going, a couple of years before we went. They made the plan before we split up. It put quite a lot of pressure on me to be able to afford to pay for three of us to go to America...So I kept saving a little bit but as I was saving on one hand I was using the credit card in the other hand.

She feels as though her parents, who regularly lend her money, have tied her into a web of obligation to go on holiday to America, and to spend what she doesn't have. Her ties to family and feelings of obligation towards them, as well as her desire for a "normal" life are folded through her relationship with credit. She feels unable to refuse others even when it impacts on her ongoing relationship to her debt. Yet Amy's father helps her manage her debt by transferring some of her debts into his name, making use of his better credit rating to secure a lower interest rate. It is these ongoing obligations, these articulations of love, hope and duty that are always part of the entangled nature of indebted lives.

Amy's financial situation, both with her current and ex-partner, tells of borrowing to please others, to keep holding on to a relationship and a semblance of a normal life: it is a gendered tale of indebted entanglements. She tells herself that it's going to be OK, but only if we keep our heads down. Yet, lying at the edges of these narratives, expressed in passing asides and expressions of desperation, is a suspicion that it is never going to be OK. The constant borrowing and juggling and struggling, the breaking down of cars, the moving house, means that every now and again more debt is added to the total. Amy's relationships constantly renegotiate this hope for the good life, through repayment, through the tightening of budgets, but all the while suspecting somewhere that it will never come. Moments of suspension - a holiday, a night out or a new sofa may enact this good life temporarily, and enable her and her partner to hold on to the idea that they work as a relationship, but underlying these mirages are the sense that the rhythms of debt repayment are never going to end. Unnecessary expenditure, enabled by credit, is the one moment in which she is able to hold on to an image of how the relationship, and the family, could or should have been. That is, credit offers a suspension of the destruction of family by debt repayment, a momentary image of how family relationships could or should be. Part of this is simply having the life that they cannot otherwise enjoy. But in that moment of expenditure the initial source of the problem - ongoing debt repayments, servicing high levels of interest - is obscured or forgotten. This reflects the ways in which credit is sold (think back to the Clearscore advert at the beginning of the paper) not only as enabling a moment of enjoyment, but also creating a moment of a life in which expenditure is not subject to neverending restriction.

The tying of being out of debt with new life is given literal force in Claire and Simon's case. A couple in their thirties with a new baby, their debts accumulated after they left their London jobs to pursue a dream of living a rural life and were unable to find well-paid work. Simon took out a career development loan and used it to pay the mortgage on their new home. Being out of London, they found they were much more dependent on their car, which kept breaking down, causing more debt. They wanted to have their first child, but as their debt grew they found it difficult to conceive. 
"We tried for about three years and it just didn't happen, but then, nice coincidence, when we came out of debt and our minds were clear and everything, we went through IVF and it happened! So it's like we needed to be in a good place, and that was out of debt, comfortable, happy. We were trying for such a long time and we kind of feel that it was because we were under pressure. It wasn't a good nest, it wasn't a good atmosphere [....] Our bodies only got ready for babies when they could tell it was a good thing."

What Claire and Simon express explicitly is a theme that runs through Shelley, Amy and Martin's accounts; that the ongoing repayment of debts is the principal factor restricting their happiness in the present. Yet, as part of locating the source of difficulty, each of these individuals enact certain practices - going on holiday, buying things for their children - that help to mitigate their ongoing anxiety about themselves and the future. That is, these practices enact a momentary suspension of the conditions of struggle, in part because they ignores or obscures the source of the problem.

Presentations of debt in popular media focus upon gendered profligate spending: stories of rising household debt are illustrated with images of women carrying multiple shopping bags (Ramsay 2009). Yet in relationships in which debt is a continual source of anxiety, forms of consumption that enable a belief in, and hope for, intimate and family relationships become extremely powerful. In the next section we explore the varied ways in which relational selves find such moments of escape.

\section{Escape}

Hypervigilance, and the ongoing pressure of austere life, provides the conditions for practices and spaces that offer suspension or escape from the background hum. Where people worry and juggle financial lives, hypervigilance creates spaces where these worries can be put at bay. The disciplinary temporality of hypervigilance thus invites a desire for suspension and interruption through the creation of experiential spaces of denial, avoidance and escape. Yet these spaces are also enabled by and incorporated into the credit cycle - the credit industry offers "affective lures" that offer a temporary space where money 'doesn't matter'. As Clearscore, online banking, and credit card companies offer more loans, a space opens up for the production of a temporary moment of having what you want. An imaginary horizon of debt-free life enables technologies such as the UK National Lottery to participate in these spaces - practices that offer immersion in another world where calculation, vigilance and decision making are limited.

What is experienced as a slow death, survival and overwhelming responsibility can be suspended in acts of sensory and embodied intensity and immersion: in food, sex and spending. When Amy discusses her Barclays app that offers her a loan each time she checks her balance, or when we consider the technologies through which Clearscore functions, we can see how the relationship between hypervigilance and escape work to lock people further into indebted lives. The conditions for one produce the other, as the unbearable state of hypervigilance requires interruptions from its constancy. Ryan Davey's ethnography of indebted life in the UK discusses the emergence of "makeshift zones of debt evasion" (Davey 2015). These involve the securing of the phenomenological space against incursions from debt collection technologies, such as unplugging phones, words of negation and immersion in home cinema and video gaming (see also Han, 2015). Similar ethnographic attention to moments of suspension is seen in Dow Schull's work on machine gambling in Las Vegas, where the machine gambling interface engenders for her informants moments of dissolution of self and world (Schüll 2012). The machine is a sociotechnical construction: a closed in space of suspension where all that matters are the minute decisions of which card right now. It provides an interface of total absorption and distillation of risk, in contrast to contemporary American lives, to the overwhelming feeling of an abundance of choice with no controllable variables, and to the need to constantly manage contingency on a seemingly limitless plane. 
Some such zones are in part formed by refusal. For Stuart, the refusal of debt involves a long term waiting game. Stuart is 39 and has a history of 'problem debt,' amounting to around $£ 40,000$ from a period in his twenties when he was in a destructive relationship that circled around the couple's attachments to drinking, drugs and gambling. His recovery from this, and the articulation of his problem, has enabled him to adopt an attitude towards his debt and the debt industry that has released him from the responsibility of repayment, by transferring blame onto the debt and gambling industry that enabled and solicited his addictions. By repositioning his past self as responding to affective lures and compulsive drives, and refusing to respond to them, he has been able to swerve the forms of affective capture that, DeVille argues, enable debt collection strategies (Deville 2015). Instead, Stuart argues, "they're gambling on me a bit, aren't they - in terms of how much they can lend me and I'll still pay it back. But when you reach a certain level of problem debt, the only solution you can think of is just to get in more debt. You stop thinking about whether you will pay it back".

S After a while, there's a funny thing that happens - if you owe the bank money they'll sell it on, won't they....and then your debt becomes a sort of traded commodity. It becomes a bit more removed, less like a standard borrowing and lending transaction and becomes less of an obligation. And then you start thinking, "why should I"? You're getting letters from people who use stronger tactics than the bank - more threatening language. They know that by using more aggressive tactics, they'll get the money. They're gambling too.

LD: What happened when you got a letter?

S Binned it. Occasionally l'd open it just out of curiosity.

He discusses how he and his former partner "egged each other on. We were both reckless. But when you get in debt, one option is to go mental. If you go mental, you can't pay it back.... once I owed $£ 1,000$ that I couldn't pay back, I knew".

Stuart here is articulating the sense that many of our interviewees had, that, after a certain point, debt becomes a way of life. The debt-free horizon, although articulated at various time, becomes a fiction, and the means through which that might occur are largely unavailable.

\section{LD: did you engage with the creditors at all?}

$S$ What's the point - I owe so much. I always had in my mind that if I blanked them long enough, they'd just fuck off.

This response to the threat of enforcement is echoed among Ryan Davey's participants (Davey 2015). Davey notes in this respect that "despite the familiarity and apparent self-evidence of the idiom 'fuck off', it is worth noting that it has at least two meanings.... Pete was at one and the same time refuting the claim that legal enforcement was imminent and telling the creditor to go away". Davey argues that the performative "fuck off" operates to suspend liability and obligation. Whilst not a direct refusal of debt, it serves as a temporary distancing from the forms through which it is made present (Davey, forthcoming).

For Stuart, then, an alternative topology of morality is produced that enables him to refuse to become the "indebted man". He is prepared to sit it out, to enter into a stand-off against his creditors until he is given up as a hopeless case. While in his previous relationship, the thrill of taking out loans, spending, gambling and drug-taking was central to the building of intensity between him and his partner, his current life with partner and children and a steady income involves a stemming of the most destructive sides of his being and a commitment to stick to the 'straight and narrow'. The temporality of this indebted life looks ahead, not to when debts are to be paid, but when they are to be written off. 
Tim is 37 and works as a freelancer. The patchy nature of his income, combined with the high cost of renting a home and what he calls being 'bad with money' have all contributed to his being $f 28,000$ in debt - a mix of bank overdrafts, credit cards and loans from family and friends. Like Stuart, Tim sees his debt as political and has largely ignored it until recently:

Modern society is fuelled by debt and that's how they power the system. It's like, house prices going up is basically borrowing money from the future isn't it? But at the same time it's labelled as your responsibility, and the regulatory powers have been stripped back haven't they? I mean credit cards, they say it's all your responsibility but their whole business model is based on you not paying it back on time. So society is saying it's morally wrong to be in debt but then it's also constructed not just to allow you to go into debt but to need you to go into debt.

Tim's choice of work is in some ways, an act of political defiance. It requires him to be in debt (to hire equipment, to wait for long periods to get paid after completing jobs, to take on work that doesn't pay but might lead to more interesting work in future) but he sees this lifestyle - despite the debt that comes with it - as liberating. But nagging doubts are creeping in to his sense of liberation:

But maybe I'm thinking differently about it now. I'm never going to be able to afford a house, and I'm never going to have savings for a deposit. But then I think a lot of people are in that position now and I would rather not conform to all these shit jobs like finance or advertising just to be able to afford a house. Those people living those lives are not necessarily any happier. But at the same time, you do worry about what you'll do in middle age or late age. I don't think you can predict. Maybe you'll just meet someone, or move to Portugal...

Working on a freelance basis allows Tim to see his debts in a different timescale, though he admits the reality doesn't always match the way he sees them:

I think if I had a regular job with a salary, being $£ 10,000$ or $£ 15,000$ in debt would feel like a lot because I would know how long it would take me to pay it off. But because I'm freelance my work is unpredictable, so something might come in that might allow me to whip off a third, or half of my debt in one go. But the thing is that never happens, because even if it does, there's things like taxes which you haven't allowed for so suddenly in January that's a few grand. So you might get the big job but suddenly that's eaten up again and you're still in the same amount of debt and it accrues a little bit more each time.

As Tim's account shows, while Stuart's case is extreme, it is certainly not unusual. Other zones of debt evasion tend to be more temporary, and less about refusing to acknowledge the existence of a debt. Buying scratch-cards or taking out a hire-purchase agreement on a sofa involve sociotechnical infrastructures that enable speculative moments of pleasure and fulfilment - a gamble on the possibility of escaping the struggle of everyday indebted life. Such sociotechnical forms enable moments of temporary escape and release, providing moments of suspension that in turn maintain and enhance attachments to debt. These are moments of mitigation in which the subject refuses to recognise that life has become an indefinite struggle, or that relationships and life projects have not worked out as intended. Dawney has discussed the concept of the interruption: a moment of intensity through which the politics that constitute bodies make themselves known and felt (Dawney, 2013). Here, the interruption is experienced as an affective break from the low-level affect domains, described here through the themes of 'hypervigilance' and 'slow death' - that colour lives in conditions of austere survival. Sometimes, the background noise, the pressure building, the subconscious knowing that something isn't right, can be noticed, but sometimes you can't - you don't want to - ever really recognise what it is, because to do so is to give in and give up. So you 
punctuate your world with that which makes you feel something different. And it is through the recognition of such interruptions as interruptions, as a break from those generalised domains of experience - the background hum of anxiety and despair - that enables us to bring our attention to how generalised those states are.

\section{Conclusion: on austerity and indebted lives}

In this paper we have entered the lives of those whose relations with the experiential modes of austerity and indebtedness have conditioned their worlds. These people reveal complex interrelations of finance, care, love and attachment. They experience often conflicting affective demands, pulled in various directions by partners, technologies of the debt industry, family and friends, and by desires for a good or respectable life or to be part of something greater than themselves.

Inasmuch as our participants' experiences reflect a hypervigilant attention to debt, and the ongoing conditions of attrition we address in terms of 'slow death', they are less the 'victims' of austerity than its idealised subjects: the end point to which restructurings of welfare and work are driven. We began by noting in this respect Martijn Konings' argument that austerity was not an 'external' condition imposed upon democracies; however extra-ordinary and atavistic these policies appeared to right-thinking social scientists and economists, it is misguided to interpret them through the model of the Schmittian exception. Rather, austerity measures found considerable democratic support from existing imaginaries regarding the purification of our relationship to money. We would draw attention, in turn, to how they resonated with the affective states described in this paper; of life lived in a state of heightened anxiety as the subject accepts the responsibility of negotiating its own hopes, relationships and temporal horizons through the possibilities and demands of credit; and of the regret over previous spending that generates an intense desire to save and cut away at whatever is joyous in life.

Without explicitly realising it, these lives have been slowly re-shaped by the same austerity measures. As we have noted, our research participants do not primarily define their life problems in terms of debt. While debt was recognised to be ever-present - always exacerbating and intensifying its surrounding problems and demarcating its own space of anxiety, participants were more likely to identify working conditions, failed relationships or a precarious housing situation as the source of their problems. In each of these cases, increased levels of precarity and risk can be located to specific changes introduced under the banner of austerity, whether the removal of state support for mortgage interest, the freeze on tax credits, or removal of access to Legal Aid for family matters. That is, inasmuch as our participants lived in a state of heightened awareness, reflection and vigilance, attending to their financial lives and articulating their conditional presents and futures, they are not only the affective domains upon which austerity found resonance and support, but domains that have been amplified and intensified by programmes of welfare reform and funding cuts.

Yet our emphasis upon a third area of experience - escape - highlights that, pace Lazzarato's account of an all-consuming framework of power oriented around the creditor/debtor nexus, there is more to indebted life than the practices of self-discipline and regularisation of time that constitute indebted subjectification. By ignoring or displacing the ongoing restrictions imposed by debt, or making a lifestyle out of certain practices of escape, our participants' accounts highlighted the importance of moments in which these conditions are suspended. While it became clear the forces of hypervigilance and slow death operated at their most stark and cruel point when targeting the most vulnerable, and via gendered affective vectors of love, obligation and responsibility, these demands, and the anxiety that they provoke, also lead to specifically gendered and relational strategies for their alleviation and for their mollification. 
Atfield, G., R. Lindley, et al. (2016). Living with debt after advice. York, Friends Provident Foundation. Baraitser Lisa. (2017) Enduring time, London: Bloomsbury Publishing.

Barnwell, A. (2016). "Creative paranoia: Affect and social method." Emotion, Space and Society 20(Supplement C): 10-17.

Bear Laura. (2015) Navigating austerity: currents of debt along a South Asian river: Redwood City: Stanford University Press.

Berlant, L. G. (2011). Cruel optimism, Duke University Press Durham, NC.

Berlant, L. G. (2015) "Do you intend to die: Lauren Berlant on Intimacy after Suicide." Kings Review 2017.

Clarke, J. and J. Newman (2012). "The alchemy of austerity." Critical Social Policy 32(3): 299-319.

Coleman, R. (2016). "Austerity futures: debt, temporality and (hopeful) pessimism as an austerity mood." New Formations 87(87): 83-101.

Davey, R. (2015). Debts in Suspense: Coercion and optimism in the making of class in England, University of Cambridge.

Davey, R. (forthcoming). "Scenes of indebted optimism: reality and space among working-class debtors in England." Geoforum.

Davies, W., J. Montgomerie, et al. (2015). Financial Melancholia: Mental Health and Indebtedness. London, Political Economy Research Centre.

Deville, J. (2013) "Leaky data: How Wonga makes lending decisions," Charisma Network, May 20, 2013. Available from http://www.academia.edu/download/34144234/Deville_-_2014__Leaky_data.doc

Dawney, L. (2013). "The interruption: investigating subjectivation and affect." Environment and Planning D: Society and Space 31(4): 628-644.

Dean, J. (2010). Blog theory: Feedback and capture in the circuits of drive, Polity.

Deville, J. (2015). Lived Economies of Default: Consumer Credit, Debt Collection and the Capture of Affect, Routledge.

Guérin, I. (2014). "Juggling with debt, social ties, and values: the everyday use of microcredit in rural South India." Current Anthropology 55(S9): S40-S50.

Hall, S. M. (2016). "Everyday family experiences of the financial crisis: getting by in the recent economic recession." Journal of Economic Geography 16(2): 305-330.

Han, C. (2012). Life in debt: Times of care and violence in neoliberal Chile. Oakland: University of California Press.

Harker, C. (2017). "Debt space: Topologies, ecologies and Ramallah, Palestine." Environment and Planning D: Society and Space: 0263775816686973.

Helms, G., M. Vishmidt, et al. (2010). "Affect \& the Politics of Austerity: An interview exchange with Lauren Berlant." Variant 39/40: 3-6.

Hynes, S. (2013). "Austerity justice." Journal of Poverty and Social Justice 21(1): 97-100.

Joseph, M. (2014). Debt to Society: Accounting for Life under, University of Minnesota Press.

Kirwan, S. (2016). "The UK Citizens Advice service and the plurality of actors and practices that shape "legal consciousness"." The Journal of Legal Pluralism and Unofficial Law 48(3): 461-475.

Konings, M. (2015). The emotional logic of capitalism: What progressives have missed, Stanford University Press.

Langley, P (2014). "Equipping entrepreneurs: consuming credit and credit scores." Consumption Markets \& Culture Volume 17(5): pp. 448-467.

Lazzarato, M. (2012). The making of the indebted man: an essay on the neoliberal condition. Los Angeles, Calif, Semiotext(e). 
Montgomerie, J. and D. Tepe-Belfrage (2016). "Caring for debts: how the household economy exposes the limits of financialisation." Critical Sociology: 0896920516664962.

Morris, L. (2016). "The moral economy of austerity: analysing UK welfare reform." The British Journal of Sociology 67(1): 97-117.

O'Hara, M. (2015). Austerity bites: A journey to the sharp end of cuts in the UK, Policy Press.

Peebles, G. (2012). "Whitewashing and leg-bailing: on the spatiality of debt." Social Anthropology 20(4): 429-443.

Poon, M. (2007) "Scorecards as devices for consumer credit: the case of Fair, Isaac \& Company Incorporated" The Sociological Review. Vol.55(2), pp. 284-306

Povinelli Elizabeth A. (2016) Geontologies: A requiem to late liberalism, Duke University Press.

Povinelli Elizabeth A. (2011) Economies of abandonment: social belonging and endurance in late liberalism, Duke University Press.

Santos, R. D. (2015). Navigating the New Normal: Why working families fall into problem debt and how we need to respond, StepChange.

Schüll, N. D. (2012). "Gambled away: Video poker and self-suspension." Anthropology Now 4(2): 113.

Seigworth, G (2016) "Wearing the world like a debt garment: Interface, affect, and gesture." Ephemera Volume 16(4): pp.15-31

Standing, G. (2016). The precariat: The new dangerous class, Bloomsbury Publishing.

Wilkis, A. (2015). "The Moral Performativity of Credit and Debt in the Slums of Buenos Aires." Cultural Studies 29(5-6): 760-780.

Zhang, Y. Jia, H., Diao, Y., Hai, M., Li, H. (2016) "Research on Credit Scoring by Fusing Social Media Information in Online Peer-to-Peer Lending" Procedia Computer Science Volume 91, 2016, Pages 168-174 